\title{
Efficacy of two plant powders as cowpea grain protectants against Callosobruchus maculatus Fabricius (Coleoptera, Chrysomelideae: Bruchinae)
}

\author{
Daniel Chepo CHOUGOUROU1, Christophe Homevo AGOSSA2, Yedomon Ange Bovys \\ ZOCLANCLOUNON ${ }^{1}$, Medewouin Genice NASSARA ${ }^{1}$, Alphonse AGBAKA ${ }^{1}$ \\ ${ }^{1}$ Laboratoire de Recherche en Biologie Appliquée (LARBA), University of Abomey-Calavi (UAC), P.O. Box 2009 Cotonou, \\ Republic of Benin. \\ ${ }^{2}$ Ecole de Gestion et de Production Végétale et Semencière (EGPVS), University of Agriculture of Ketou (UAK), P.O. Box \\ 43 Ketou, Republic of Benin. \\ Corresponding author: Daniel Chepo CHOUGOUROU; E-mail address: chougouroud@yahoo.de; \\ Tel: (00229) 97337018.
}

Original submitted in on 22nd July 2016. Published online at www.m.elewa.org on $30^{\text {th }}$ September 2016 http://dx.doi.org/10.4314/jab.v105i1.11

\begin{abstract}
Objective: This study was carried out to study insecticidal effect of powders from Chenopodium ambrosioides leaves and Aframomum melegueta seeds on cowpea weevil Callosobruchus maculatus.

Methodology and Results: $5 \mathrm{~g}$ of both powders of $A$. melegueta and $C$. ambrosioides were used in the proportions of $C$. ambrosioides 100\%:A. melegueta $0 \%, C$. ambrosioides $0 \%$ : A. melegueta $100 \%, C$. ambrosioides 30\%: A. melegueta 70\%, C. ambrosioides 70\%: A. melegueta 30\% and C. ambrosioides $50 \%$ : A. melegueta $50 \%$. Plant powders were added to $20 \mathrm{~g}$ of cowpea grains. Bioassays were conducted at $26.64 \pm 0.74^{\circ} \mathrm{C}$ and $72.55 \pm 4.38 \%$ relative humidity. Insect mortality was evaluated from 24 to 144 hours after treatment. Results obtained indicated that plant powders had significant effect on $\mathrm{C}$. maculatus mortality. The highest mortality rate $(70.00 \pm 26.45 \%)$ was recorded in jar treated with C. ambrosioides.

Conclusion and application of findings: Either plant powders, alone or mixed had high insecticidal effect on $C$. maculatus. Because of their effectiveness, these plant powders could be recommended as grain protectants against $C$. maculatus.
\end{abstract}

Key words: Chenopodium ambrosioides, Aframomum melegueta, Callosobruchus maculatus, Insecticidal activity

\section{INTRODUCTION}

Cowpea, Vigna unguiculata (L.) Walp., is an important component in diet of southern Benin population. Postharvest losses due to cowpea beetle Callosobruchus maculatus (Coleoptera: Chrysomelidae, Bruchinae) are well documented (Emeasor, 2005; Udo and Epidi, 2009; Gusmão et al., 2013). C. maculatus is a cosmopolitan pest of cowpea. It is both field and stored pest. Infestation often begins in the field when pods are mature (Sathyaseelan et al., 2008) and when seeds are harvested and stored, the pest population increases rapidly and results in total destruction during short period of 3-4 months (Rahman and Talukder, 2006). Synthetic insecticides employed in the control of cowpea beetle 
proved effective, very expensive and unavailable at critical periods and they sometimes constitute health hazards to consumers (Lale, 2002). Due to the accumulation of residues of chemicals in grains, the selection of resistant insect population and other side effects, alternative approaches in Integrated Pest Management (IPM) have been considered. There is now renewed interest in the use of pesticides of plant origin in order to obviate the problems of environmental pollution, killing of non-target species and humans as well as reducing cost of purchasing synthetic chemical pesticides. In this context, several plants and constituent bioactive substances, also called insecticides of plant origin or botanical insecti-

\section{MATERIALS AND METHODS}

Insects rearing: Adults of $C$. maculatus were reared in the laboratory under $26.64 \pm 0.74^{\circ} \mathrm{C}, 72.55 \pm 4.38 \%$ r.h. and $12 / 12$ hours photoperiod. The original stock was obtained from stock cultures of Laboratory of Research and Applied Biology of University of Abomey-Calavi (Benin). All grains used for this study were purchased at the market (the international market of Dantokpa, Cotonou, Benin).

Collection and preparation of plant materials: $A$. melegueta seeds were purchased at the market of Zobe $\left(6^{\circ} 27^{\prime} 33.768^{\prime \prime} \mathrm{N}, 2^{\circ} 11^{\prime} 13.394^{\prime \prime} \mathrm{E}\right)$ and C. ambrosioides leaves were collected at Kpomasse $\left(6^{\circ} 25^{\prime} 44.868^{\prime \prime} \mathrm{N}\right.$, $2^{\circ} 0^{\prime} 48.096$ 'E). Both markets were in Ouidah district (Southern Benin). The National Herbarium of Benin identified plant materials. They were air dried on laboratory benches for 22 days at room temperature $\left(25^{\circ} \mathrm{C}-27^{\circ} \mathrm{C}\right)$ before grinding in an electric mill and sieved through a mesh of 250- $\mu \mathrm{m}$ size.

Experimental set up: Plant powders were thoroughly mixed with $20 \mathrm{~g}$ of cowpea grains in $250 \mathrm{ml}$ glass jars. $5 \mathrm{~g}$ of both powders of $A$. melegueta and $C$. ambrosioides were used in the proportions of $C$. ambrosioides 100\%:A. melegueta $0 \%$ (T1), C. ambrosioides $0 \%$ : A. melegueta 100\% (T2), C. ambrosioides 30\%: A. melegueta 70\% (T3), C. ambrosioides 70\%: A. melegueta 30\% (T4) and

\section{RESULTS}

Analysis of variance indicated highly significant differences of mortality rates among various treatments ( $p$ $<0.001)$, exposure duration $(p<0.001)$ and combined effect of treatment and exposure duration $(p<0.001)$. Mortality rates of $C$. maculatus with exposure time are given in Table 1. All treatments exhibited varying degrees cides, have been tested and considered promising in the control of cowpea beetle (Denloye et al., 2010, Kheradmand et al., 2010, Udo, 2011). Chenopodium ambrosioides Linn and Aframomum melegueta K. Schum were chosen because they have shown promise of medicinal and insecticidal activity in Malawi, Central Africa countries such as Cameroon and Gabon and Southern Africa (Gadano, 2002, Tapondjou et al., 2002, Konning et al., 2004; Okwu, 2005, Odugbemi, 2006, Denloye et al., 2009). This study aimed to assess insecticide effect of $C$. ambrosioides leaf and $A$. melegueta seed powders against $C$. maculatus during in stored cowpea.

C. ambrosioides 50\%: A. melegueta 50\% (T5). For each set of treatments, a non-treated seeds was considered as control. Ten unsexed $C$. maculatus (1-5 days old) adults were randomly selected and introduced to each of the containers. Three replicates of the treatments and untreated controls were laid out in a completely randomized design.

Data collection: The number of dead insects in each jar was counted 24, 48, 72, 96, 120 and 144 hours after treatment and the Mortality Rate (MR) was calculated with following formula:

$$
M R(\%)=\frac{\text { Number of dead insects }}{\text { Total number of insects }} \times 100
$$

Dead C. maculatus were removed and discarded after every count. Control serves as comparison to treated jars. Data analysis: Data were analyzed using statistical program R 3.3.1 (R Core Team, 2016). Analysis of variance (ANOVA) was used to compare treatments using aov function of agricolae package (de Mendiburu, 2015). Significant differences between means were determined by the Least Significant Differences (LSD) $(P \leq 0.05)$ using LSD. test function of agricolae package (de Mendiburu, 2015).

of insecticidal activities killing $C$. maculatus adults more than control at the $5 \%$ level of probability. Mortality rates increased proportionally with duration of exposure time. At 72 hours after treatments application, $C$. ambrosioides caused the highest mortality of $83.33 \pm 20.81 \%$ followed 


Chougourou et al. J. Appl. Biosci. $2016 \quad$ Efficacy of two plant powders as cowpea grain protec-
tants against Callosobruchus maculatus Fabricius (Coleoptera, Chrysomelideae: Bruchinae)

by mixture of C. ambrosioides (70\%) and $A$. melegueta

(30\%) with $70.00 \pm 10.00 \%$.

Table 1. Mortality of $C$. maculatus with treatments exposure duration

\begin{tabular}{l|l|l|l|l|l|l}
\hline & \multicolumn{7}{|c}{ Mean mortality rate (\%) of C. maculatus at: } \\
\hline Treatment & 24 HAT & 48 HAT & $\mathbf{7 2 ~ H A T}$ & 96 HAT & 120 HAT & 144 HAT \\
\hline T1 & $26.66 \pm 20.81 \mathrm{a}^{*}$ & $70.00 \pm 26.45 \mathrm{a}$ & $83.33 \pm 20.81 \mathrm{a}$ & $96.66 \pm 5.77 \mathrm{a}$ & $100 \pm 0.00 \mathrm{a}$ & $100 \pm 0.00 \mathrm{a}$ \\
\hline T2 & $10.00 \pm 10.00 \mathrm{ab}$ & $26.66 \pm 15.27 \mathrm{~b}$ & $50.00 \pm 0.00 \mathrm{~b}$ & $66.66 \pm 11.54 \mathrm{~b}$ & $83.33 \pm 5.77 \mathrm{bc}$ & $93.33 \pm 5.77 \mathrm{ab}$ \\
\hline T3 & $6.66 \pm 5.77 \mathrm{~b}$ & $23.33 \pm 11.54 \mathrm{bc}$ & $50.00 \pm 10.00 \mathrm{~b}$ & $70.00 \pm 0.00 \mathrm{~b}$ & $76.66 \pm 5.77 \mathrm{~cd}$ & $86.66 \pm 5.77 \mathrm{~b}$ \\
\hline T4 & $3.33 \pm 5.77 \mathrm{~b}$ & $36.66 \pm 5.77 \mathrm{~b}$ & $70.00 \pm 10.00 \mathrm{a}$ & $86.66 \pm 5.77 \mathrm{a}$ & $93.33 \pm 11.54 \mathrm{ab}$ & $96.66 \pm 5.77 \mathrm{a}$ \\
\hline T5 & $6.66 \pm 5.77 \mathrm{~b}$ & $23.33 \pm 5.77 \mathrm{bc}$ & $50.00 \pm 0.00 \mathrm{~b}$ & $63.33 \pm 5.77 \mathrm{~b}$ & $66.66 \pm 5.77 \mathrm{~d}$ & $73.33 \pm 5.77 \mathrm{c}$ \\
\hline Control & $0.00 \pm 0.00 \mathrm{~b}$ & $0.00 \pm 0.00 \mathrm{c}$ & $6.66 \pm 5.77 \mathrm{c}$ & $20.00 \pm 10.00 \mathrm{c}$ & $23.33 \pm 5.77 \mathrm{e}$ & $26.66 \pm 5.77 \mathrm{~d}$ \\
\hline LSD Value & 18.27 & 24.44 & 18.75 & 13.25 & 11.85 & 9.37 \\
\hline
\end{tabular}

*Means in each column bearing the same letter (s) are not significantly different at the $5 \%$ level of probability by Least Significant Difference test. T1: C. ambrosioides 100\%:A. melegueta0\%, T2: C. ambrosioides0\%: A. melegueta100\%, T3: C. ambrosioides30\%: A. melegueta70\%, T4: C. ambrosioides 70\%: A. melegueta30\% and T5: C. ambrosioides 50\%: A. melegueta 50\%; HAT: Hour after treatment. LSD: Least Significant Difference

Mean mortality rate of $C$. maculatus adults is slightly highest in cowpea grains treated with powder mixture of C. ambrosioides $(70 \%)$ and $A$. melegueta $(30 \%)$ $(93.33 \pm 11.54 \%)$ followed by $C$. ambrosioides $(0 \%)$ and $A$. melegueta (100\%) (83.33 $\pm 5.77 \%)$ and $C$. ambrosioides $(30 \%)$ and $A$. melegueta $(70 \%)$ mixture $(76.66 \pm 5.77 \%)$. The lowest mortality rate $(23.33 \pm 5.77 \%)$ was recorded in control jar at 120 hours after treatment. Mortality rate

\section{DISCUSSION}

The present study revealed that $C$. ambrosioides and $A$. Melegueta, alone or in mixture had insecticidal activity against $C$. maculatus and can be used for the control of the bruchid. Some studies proved efficacy of $C$. ambrosioides for controlling $C$. maculatus including toxicity to adults, reduction of oviposition, ovicidal activity and toxicity to immature stages prior to or immediately following penetration of plant tissue (Tapondjou et al., 2002; Emeasor, 2005; Denloye et al., 2010). High mortality rates obtained in this study are in accordance with the results reported by Chougourou et al., 2015, which had $100 \%$ of mortality of $C$. maculatus with $1.5 \mathrm{~g}$ of $C$. ambrosioides per $20 \mathrm{~g}$ of Vigna subterranea, 120 hours after treatment. Results showed significant insecticidal effect of A. Melegueta. Adesina et al., 2015 demonstrated in their work insecticidal effect, oviposition deterrent effect and adult emergence reduction of $A$. Melegueta on $C$. maculatus. A. melegueta seed powder caused $81.14 \%$ adult mortality at dose of $2.5 \mathrm{~g}$ for $20 \mathrm{~g}$ cowpea 120 hours after treatment. Results also revealed mixture of two botanicals at ratio $70: 30,30: 70$ and 50:50 had significant insecticidal effect (more than 60\%, 96 hours after treatment). This shows that both powders contained toxic ingredients for C. maculatus. High insecticidal effect of both botanicals recorded with all treatments were significantly different from each other $(p<0.05)$ at 120 hours after treatment. The mortality effect by $C$. ambrosioides (T1) was significantly higher than that of mixture $\mathrm{T} 3(\mathrm{C}$. ambrosioides 30\%: A. melegueta 70\%) and mixture T5 (C. ambrosioides 50\%: A. melegueta $50 \%$ ) but did not differ significantly from that of T4 (C. ambrosioides 70\%: A. melegueta $30 \%), 144$ hours after treatment $(p<0.05)$.

may be due to its physical action since the particles may block spiracles of $C$. maculatus and cause death by asphyxiation. Although there is no direct evidence of this in the present work, earlier works such as those of Ofuya and Dawodu (2002) showed that there is a direct relationship between particle size of plant powders and insect mortality in treated grains. Fine particle size aids even distribution of powders on the surface of seeds and the walls of the storage container thus increasing their possibility of making contact with the insects and killing them. In addition, plant powders cause abrasion of insect cuticle and lead to water loss (Sousa et al., 2005), which may cause stress and eventual death. Insecticidal effect of both botanicals may also due to its active components. Phytochemical screening of $C$. ambrosioides revealed the presence of alkaloids, tannins, saponins, flavonoïds, terpenes, sterols, cardenolide aglycone, volatile oils and carbohyfrates (Okhale et al., 2012). Adesina et al. (2015) revealed after phytochemical analysis, the presence of tannins, cardiac glycosides, saponins, alkaloids and flavonoids in A. Melegueta. Karamanoli et al. (2011) reported that tannins exert their action by combination of mechanism that includes iron chelation and enzyme inhibition. However, the exact mechanism behind the ob- 


\section{Chougourou et al. J. Appl. Biosci. 2016 Efficacy of two plant powders as cowpea grain protec- tants against Callosobruchus maculatus Fabricius (Coleoptera, Chrysomelideae: Bruchinae)}

served action of both plant powders is not yet known. Dolui et al. (2012) reported that tannin combined with protein to inhibit enzyme activity and reduce the availability of protein in haeolymph in insects. Some of the reported observed effects of saponins are increased mortality, lowered food intake, weight reduction, retardation in development and decreased reproduction (Chaieb, 2010). Adedire and Lajide (1999) reported 6-paradol, 6-gingerol

\section{CONCLUSION}

The findings of this research have shown insecticidal effects of plant powders. These results indicate that both plant powders have potential for cowpea grain protection. They can be used as an alternative to synthetic insecticides. Accurate identification and isolation of bioactive

\section{ACKNOWLEDGEMENTS}

The authors are grateful to Aimé BOKONON GANTA PhD., Lecturer at Faculty of Agricultural Sciences of Uni-

\section{REFERENCES}

Adedire CO. and Lajide L, 1999. Toxicity and oviposition deterrence of some plants extracts on cowpea storage bruchid, Callosobruchus maculatus (Fabricius). J. Plant Dis. Protect. 106:647-653.

Adesina JM, Jose AR, Rajashaker Y, Afolabi LA, 2015. Entomotoxicity of Xylopia aethiopica and Aframomum melegueta in suppressing oviposition and adult emergence of Callosobruchus maculatus (Fabricius) (Coleoptera: Chrysomelideae) infesting stored cowpea seeds. Jordan Journal of Biological Sciences, 8(4):263268.

Akinbuluma MD, Adepetun MT, Yeye EO, 2015. Insecticidal effects of ethanol extract of Capsicum frutescens and Dennettia tripotala against Sitophilus zeamais Motschulsky on stored maize. International Journal of Research in Agriculture and Forestry, 2(11):1-7.

Chaieb I, 2010. Saponins as insecticides, A Review. Tunisia J. Plant Protect. 5: 39-50.

Chougourou CD, Zoclanclounon YA, Agbaka A, Togola A, 2015. Toxicity of two plant powders as biopesticides in the management of Callosobruchus maculatus F. (Coleoptera: Chrysomelidae, Bruchinae) on two stored grain legumes. Journal of Applied Biosciences, 86: 7900-7908.

de Mendiburu F, 2015. Agricolae tutorial version 1.2-2. Statistics and informatics department of economic faculty of National University of Agriculture Molina. Peru. 78pp. and 6-shagaol (an alkyl phenol aromatic ketones) as the major insecticidal constituent of $A$. melegueta, which is responsible for sharp and peppery taste of the seeds. Owokotomo et al. (2014) reported that $A$. melegueta contains the following bioactive molecules: a- caryophyllene, $\beta$-caryophyllene, E-nerolidol, linalool, gingerdione, paradol, shagaol and humulene.

ingredients of these plant extracts should be explored as key issue for further study. Further research activities should be carried out against other storage insect pests and in the field against pests of field crops.

versity of Abomey-Calavi and Lazare DJOSSOU Ing, for their technical assistance.

Denloye AA, Ajelara OK, Olowu RA, Eshilokun AO, Makanjuola WA, 2009. Insecticidal activity of petroleum ether extract and essential oil of Chenopodium ambrosioides L. (Chenopodiaceae) against Anopheles gambiae (Diptera: Culicidae). Acta Entomol. Sin. 52 (8):923-928.

Denloye AA, Makanjuola WA, Teslim OK, Alafia OA, Kasali AA, Eshilokun AO, 2010. Toxicity of Chenopodium ambrosioides L. (Chenopodiaceae) products from Nigeria against three storage insects. Journal of Plant Protection Research, 50(3):379-384.

Dolui AK, Debnath M, De B, Kumar A, 2012. Reproductive activities of Heliotropium indicum isolate against Helopeltis theivora and toxicity evaluation in mice. J. Environ. Biol. 33: 603- 607.

Emeasor KC, Ogbuji RO, Emosairue SO, 2005. Insecticidal activity of some seed powders against Callosobruchus maculatus (F.) (Coleoptera: Bruchidae) on stored cowpea. Journal of Plant Diseases and Protection, 112(1):80-87.

Gadano A, Gurni A, Lopez P, Ferraro G, Carballo M, 2002. In vitro genotoxic evaluation of the medical plant Chenopodium ambrosioides $\mathrm{L}$. Journal of Ethnopharmacology, 81(1):11-16.

Gusmão NMS, de Oliveira JV, Daniela M, Navarro AF, Dutra KA, da Silva WA, Wanderley MJA, 2013. Contact and fumigant toxicity and repellency of Eucalyptus citriodora Hook., Eucalyptus staigeriana F., Cymbopogon winterianus Jowitt and 
Foeniculum vulgare Mill. essential oils in the management of Callosobruchus maculatus (FABR.) (Coleoptera: Chrysomelidae, Bruchinae). Journal of Stored Products Research, 54:41-47.

Karamanoli K, Bouligaraki P, Constantinidou HI, Lindow SE, 2011. Polyphenolic compounds on leaves limit iron availability and affect growth of epiphytic bacteria. Ann. Appl. Biol. 159: 99-108.

Kheradmand K, Noori SAS, Sabahi GH, 2010. Repellent effects of essential oil from Simmondsia chinensis (Link) against Oryzaephilus surinamensis Linnaeus and Callosobruchus maculatus (Fabricius). Research Journal of Agricultural Sciences, 1:66-68.

Konning GH, Agyrae C, Enison B, 2004. Antimicrobial activity of some medicinal plants from Ghana. Fitotherapia, 15(1):65-67.

Lale NES, 2002. Stored product entomology and acarology in tropical Africa. Mole publication, Maiduguri, Nigeria, 204pp.

Odugbemi T, 2006. Outlines and Pictures of Medicinal Plants from Nigeria. University of Lagos Press, Lagos, Nigeria, 283 pp.

Ofuya $\mathrm{TI}$. and Dawodu EO, 2002. Aspects of insecticidal action of Piper guineese Schum and Thonn fruit powders against Callosobruchus maculatus $(\mathrm{F}$. (Coleoptera: Bruchidae). Nigerian J. Entomol.19:40-50.

Okhale SE, Egharevba HO, Ona EC, Kunle OF, 2012. Phytochemicaland proximate analyses and fine layer chromatrography fingerprinting of the aerial part of Chenopodium ambrosioides Linn. (Chenopodiaceae). Journalof Medecine Plants Research, 6(12):2289-2294.

Okwu DE, 2005. Phytochemicals, vitamins and mineral contents of two Nigerian medicinal plants. International Journal of Molecular Medecine and Advance Sciences 1(4):375-381.

Owokotomo IA, Ekundayo O, Oguntuase BJ, 2014. Chemical constituents of the leaf, stem, root and seed essential oils of Aframomum melegueta (K. Schum) from South West Nigeria. Intl. Res. J. Pure Appl. Chem. 4:395-401.

R Core Team, 2016. R: A language and environment for statistical computing. R Foundation for Statistical Computing, Vienna, Austria. URL: http://www.Rproject.org/.

Rahman A. and Talukder FA, 2006. Bio efficacy of some plant derivatives that protect grain against the pulse beetle, Callosobruchus maculatus. Journal of Insect Science, 6(3):19-25.

Sathyaseelan V, Baskaran V, Mohan S, 2008. Efficacy 0 $\mathrm{f}$ some indigenous pesticidal plants against pulse beetle, Callosobruchus chinensis (L.) on green gram. Journal of Entomology, 5(2): 128132

Sousa AH, Maracaja PB, Silva RM, Moura MN, Andrade WG, 2005. Bioactivity of vegetal powders against Callosobruchus maculatus (Coleoptera: Bruchidae) in Cowpea bean and seed physiological analysis. Revista De Biologia E Ciências Da Terra ,5 (2): 1-5.

Tapondjou LA, Adler C, Bouda H, Fontem DA, 2002. Efficacy of powder and essential oil from Chenopodium ambrosioides leaves as postharvest grain protectants against six stored product beetles. Journal of Stored Products Research, 38:395-402.

Udo IO, 2011. Protectant effect of plant oils against cowpea weevil (Callosobruchus maculatulus) on stored cowpea (Vigna unguiculata). Journal of Agricultural and Biological Science, 6(12):58-61.

Udo IO. and Epidi TT, 2009. Biological effect of ethanolic extract fractions of Ricinodendron heudelotii (Baill) Pierre ex Pax against Sitophilus zeamais and Callosobruchus maculatus Fabricius on stored grains. African Journal of Agricultural Research, 4(10): 1080-1085. 